\title{
Civil society development in Russian borderlands: indexes and predispositions
}

\author{
Svelana Maximova ${ }^{1}$, Oksana Noyanzina $^{1, *}$, and Daria Omelchenko ${ }^{1}$ \\ ${ }^{1}$ Altai State University, Department of Psychology of Communications and Psychotechnologies, \\ 656049, 61 Lenin ave., Barnaul, Russia
}

\begin{abstract}
The subjects of the research are preconditions of formation of civil society in six regions of the Russian Federation. The attitude towards civil society, rights and duties of a citizen, the level of responsibility for what is happening; assessment of the level of agreement and unity in society; assessment of the degree of commonality with the different categories of citizens; evaluation of the possibility of productive interaction between representatives of different social groups; the degree of participation in various types of social activities and social organizations, socio-political conditions of civil society development in the regions are determined in the research.
\end{abstract}

\section{Introduction}

Building a civil society is one of the priority tasks in contemporary Russia. The problem of civil society emerged in Russian political and public discourse in 1980s together with the formation of mass social movements [1,2]. Soon, civil society became necessary condition for social development, establishment of a welfare state and effective interaction between society and government.

Process of formation and functioning of civil society institutes in Russia entails with a number of problems [3, 4]. Thus, the Public Chamber of the Russian Federations marks weak interaction between public organizations and power institutes: non-commercial organizations often face with administrative barriers; correlation between socially useful state activity and non-commercial organizations not always occurs [5]. The other problem is the limitation of opportunities of productive communications between Russian citizens and non-commercial organizations, related with the lack of knowledge about noncommercial activity. Formation of the ways to solve these and the other problems is possible on the base of empirical; research results about conditions of development of a civil society.

\footnotetext{
* Corresponding author: noe @ list.ru
} 


\section{Theoretical background}

A civil society often understood as a set of relate vile independent public organizations, directly not associated with the government, able of express and realize interests of the citizens through self-organization, self-government and constructive dialogue with the state. The premise of the notion consists in the social need in protection from extreme outrage of the state. The formation of civil society bases on balanced combination of public and private interests with crucial significance of the last and high value of a human life, his/her rights and freedoms [6].

According to Ferguson, the higher value of the civil society should be the happiness of individuals as a fundament for shared prosperity [7]. Creation of such community is possible with understood commitment to autonomous participation in tacking socially important decisions and their implementation, creation of possibilities of such participation of the majority of citizens [8].

It is important to look for the philosophical predispositions of the notion when examining civil society. The term 'civil society' was first used by the end of XVII century in the Locke's Second Treatise of Government (1960), but here it was constructed on the base of separation of the community of citizens from natural formations and patrimonial communities, and no ideas about differences between society and the state. Locke understood civil society as a political union, based on social agreement on the contrary to the anarchy [9]. The trend can be seen in the works by Kant [10] and Jean-Jacques Rousseau [11] - the transition to civil society from natural condition reduced to the introduction of universally accepted law.

In the 'Essay on the history of the civil society' A. Ferguson (1767) clearly divides political and social spheres and marks the inconsistency between interests of the state and personality, considering the civil society as a necessary mediator. Here economic relations are the major components of a civil society [7]. Hegel, author of the first contemporary theory of a civil society [12], opposes it to the state as a sphere of private life of citizens, related to their needs and interests. He associates formation of a civil society with the statement of the bourgeois system. According to Hegel's theory, private property and equality before the law are the necessary bases for the civil society functioning. Hegel formed a dialectic sequence 'individual - family - civil society - state' there the state accumulates citizen's will through the abovementioned communities. Civil society acts as an arena for struggle and sequence between interests, but only the state is able to provide the realization of the interests [13].

Further attempts to understand the civil society were made in the Marxist theory, describing it from position of the formation approach. K. Marx and F. Engels consider civil society as an economic form in capitalistic society. The phenomenon - a Marxist point - is temporary one and has ephemeral existence [14]. A. Gramsci, in his turn, considered civil society in terms of the socialism. According to his ideas, the bases for civil society are not only material but cultural and ideological relations. In the future, civil society should replace the state's functions [15].

The system approach in sociology (Parsons, Shils, and Luhmann $[16,17,18]$ ) and general system theory [19] presented further development of civil society theory. According to the given approaches, civil society has certain system signs: it is controlling and controlled system, it has autonomy and own structure, stability and dynamism, transparency and adaptiveness, organic unity and opportunity to differentiate elements [20].

In theories related to civil society, there are the following determined indicators: democracy political regime; developed law system; guarantees of rights and freedoms in whole and for an individual, in particular; multiplicity and diversity of non-governmental public organizations; ideological multiplicity and political pluralism. The given research is 
devoted to analysis of the abovenamed indicators in contemporary Russian society in reflection of positions and attitudes of citizens.

\section{Methods}

Analysis of indexes of development of civil society realized of the base of data of sociological research 'Condition, problems and tendencies of development of the institutional and institutional trust as a social capital of civil society in six subjects of the Russian Federation' $(n=2400)$. Then research covered six regions of Russia: the Altai krai, the Jewish Autonomous oblast, the Transbaikal krai, the Kemerovo oblast, the Omsk oblast, and the Orenburg oblast.

Principles for the sampling formation included two aspects: the representativeness and the compact distribution, so we used stratified multistage sampling. Since, the sampling is the 'territorial' one, the planning considered correlation between environment and social characteristics of respondents. The sampling is valid by gender, age and type of settlement. Method of data collecting: formalized interview in households among population at the age from 18 to 75 . To base the statistical conclusion we used the corresponding statistical methods: dispersion and cluster analysis, construction of ratings.

Evaluation of condition of the observed objects based on the following indexes: understanding of the 'civil society' meaning; level of responsibility for what is happening in the country, region, city, household and courtyard; estimations about level of solidarity and unity in society; estimations about level of commonness with compatriots; estimations about opportunity of interaction between representatives of different social groups; relation to the civil rights and duties; participation in different social activities; estimations about conditions of development of civil society in region.

Data possessed with the use of statistic package SPSS 23.0 to base the logic of statistical inference, we applied corresponding to the nature of the data (nominative or quantitative) and character of distribution statistical methods (dispersion and cluster analysis, construction of ratings) [21, 22].

\section{Results}

First, we consider the meaning of the 'civil society' notion for the Russians. The most part of respondents consider civil society as a 'state of law' (39.1\%) by answering the question: 'How do you understand the 'civil society' notion, what does it mean?'. The other popular answers were: 'interests of the citizens, but not the state are in the top' $(29.5 \%)$, 'solidarity and unity between citizens' (26.6\%), 'cultural, civilized society' $(26.6 \%)$, 'all citizens of the country' $(25.0 \%)$. The answer about 'quality of all public organizations in the country' was the less popular among others - only $9.6 \%$ of respondents marked it (table 1 ). Thus, civil society is usually associated with provision of rights and realization of private interests of the citizens. We may conclude about amigos and not corresponding to the governmental point of view social representations about civil society.

Table 1. Distribution of answers to the question: 'How do you understand the 'civil society' notion, what does it mean?', \%.

\begin{tabular}{|l|c|}
\hline state of the law & 39.1 \\
\hline interests of the citizens, but not the state are in the top & 29.5 \\
\hline solidarity and unity between citizens & 26.6 \\
\hline cultural, civilized society & 26.6 \\
\hline all citizens of the country & 25.0 \\
\hline democracy & 23.8 \\
\hline
\end{tabular}




\begin{tabular}{|l|c|}
\hline opportunities of citizens to determine policy & 23.5 \\
\hline humane, moral society & 22.5 \\
\hline all non-governmental organizations of the country & 9.6 \\
\hline
\end{tabular}

One of the predispositions to the civil activity is the sense of responsibility for what is happening in society. More likely, the Russians fell themselves responsible for what is happening in own home and courtyard (feel fully responsible 15.6\%) and the country $(13.6 \%)$. These indexes have no any significant correlations with social-demographic characteristics of respondents. At the same time we fixed some differentiation in the extent of responsibility for what is happening between subjects of the Russian Federation: the most part of people who feel full responsibility is in the Omsk oblast, the Tranbaikal krai, and the Jewish Autonomous oblast $(23.5 \%, 18.2 \%$, and $16.8 \%$ correspondingly), the less part is in the Kemerovo oblast.

It is rather important to feel consent, unity and social support of surroundings in society to provide motivation to civil activity. Nowadays, more than a half of respondents $(54.2 \%)$ are sure in the prevalence of disagreement and fragmentation in contemporary Russian society. Only $30.9 \%$ marked the prevalence of consent and cohesion. And only $8.3 \%$ consider mutual understanding and cooperation between rich and poor citizens as possible, $6.9 \%$ of the Russians sure in the possibility of mutual understanding between 'ordinary people' and those who have 'a lot of power'.

The sense of community with compatriots is no less important to act in public interests, but only $76.6 \%$ of respondents indicated own affiliation with the community of the Russians (in different extent), $74.5 \%$ - with inhabitants of the own region, $77.6 \%$ - with residents of the own settlement, and $72.5 \%$ identify themselves with representatives of own ethnic group. Similar evaluations were fixed about the sense of affiliation with religion, occupation, and material well-being. The less affiliation was marked with groups of similar political views $(58.3 \%)$. Thus, the sense of unity with compatriots rather expressed despite not clear seen opportunities of fruitful collaboration with compatriots.

We estimated opinions about correlation of roles of the government and public organizations basing on agreement with the statement: 'Any reform, seriously influencing my interest should be controlled by public organizations'. The most part of respondents $(72.3 \%)$ agree with the statement; $51.0 \%$ marked that 'Part of responsibility of the power should belong to non-governmental organizations'; $69.4 \%$ - 'It is advantageous to unite with free associations by interests of citizens'; 81.3\% - 'Governmental policy must be transparent'. Therefore, the majorities of respondents are sure in the necessity of transparency and controlled characters of the government actions, at the same time the confidence in total power of the state still persists.

To make the analysis about role, rights and duties of citizens more detailed, we suggested respondents to evaluate 16 pairs of contrary statements with the scale from 1 to 6 points. According to the mean values, the Russians tend to think that it is possible to be a good citizen out of policy, without active participation in social-political events and agreement with the state. We revealed the prevalence of opinion about no need to hope for the government but cooperation of public efforts to decide social problems; everyone should think not only about him/herself but about surroundings and the country. Evaluations of respondents were close to positions 'a real citizen is responsible for own actions' and 'citizen of the country must respect the laws' rather than to the opposite. Noting, the choice of statements 'citizen of the country sounds proudly', 'all citizens feel proud about the state flag and anthem', 'a real citizen is always interested in the history of the people and the country' was rather expressed. Therefore, there are some predispositions to the formation of the civil society as a community of people who are ready for active realization of group interests in the consciousness of the Russians. 
In a result of cluster analysis by k-means method we determined three groups of respondents differ by attitudes to the civic duties (table 2). The first group (30.5\% of the sampling) is characterized by opinions about necessary political activity of citizens, agreement with the state's policy, and significant affiliation with the community. An absolute truth had statements about necessity of law-abiding and responsibility of citizens, sense of proud for own country. Representatives of the second group $(22.9 \%$ of the sampling) had rather individualist positions and deny the necessity of active participation in social life of the country and support of the major political commitments. They tend to the statements 'in some situations it is possible to act outside the law' and 'citizenship - is a formal status, emotionally neutral'. The second group tends to the statement 'each person should think about him/herself but not about the surroundings and the country' rather than the opposite one. The third group (46.6\% of the sampling) had more 'softened' positions and rather thinks that citizens are not mandatory to agree with political course and participate in policy, but must be responsible for own actions and must appreciate the affiliation with civic community.

Table 2. Distribution of respondents on clusters groped by relation to the civic characteristics of the citizenship. Results of cluster analysis, 6-point scale.

\begin{tabular}{|l|c|c|c|}
\hline & $1(30,5 \%)$ & $2(22,9 \%)$ & $3(46,6 \%)$ \\
\hline $\begin{array}{l}1-\text { 'All citizens are the unite nation and should be solidarity } \\
\text { to each other' } \\
6-\text { 'Citizens of the country are fragmented, the solidarity is } \\
\text { impossible' }\end{array}$ & 2 & 4 & 3 \\
\hline $\begin{array}{l}1-\text { 'The citizen must know own rights and duties, must fight } \\
\text { against injustice by all means' } \\
6-\text { 'It is impossible to know all laws, ordinary citizen cannot } \\
\text { confront with unlawful acts' }\end{array}$ & 2 & 4 & 3 \\
\hline $\begin{array}{l}1-\text { 'A real citizen always interested in the history of own } \\
\text { nation and country' } \\
6-\text { 'It is not necessary to know the history of the country well } \\
\text { to be a good citizen' }\end{array}$ & 1 & 4 & 2 \\
\hline $\begin{array}{l}1-\text { 'Citizens must agree with political commandments of the } \\
\text { government' } \\
6-\text { 'Citizens are not obliges to agree with the government' }\end{array}$ & 2 & 5 & 4 \\
\hline $\begin{array}{l}1-\text { 'Participation in elections is a duty for citizen' } \\
6-\text { 'Elections do not solve anything, no any sense to } \\
\text { participate them' }\end{array}$ & 2 & 4 & 3 \\
\hline $\begin{array}{l}1-\text { 'In case of emergency all capable adult citizens must } \\
\text { protect the country' } \\
6-\text { 'The army of professional military men is the only that } \\
\text { must protect the country' }\end{array}$ & 2 & 4 & 3 \\
\hline $\begin{array}{l}1-\text { 'A true citizen must be responsible for own actions' } \\
6-\text { 'Understanding of own civic responsibility and sense of } \\
\text { responsibility by citizens deprives of their liberty' }\end{array}$ & 1 & 3 \\
\hline $\begin{array}{l}1-\text { 'All citizens feel proud about the state flag and anthem' } \\
6-\text { 'Coat of arms, flag and anthem just formal symbols of the } \\
\text { state' }\end{array}$ & 1 & 4 \\
\hline $\begin{array}{l}1-\text { 'A citizen of the country - sounds proud' } \\
6-\text { 'Citizenship - is a formal status, emotionally neutral' }\end{array}$ & & 2 \\
\hline
\end{tabular}




\begin{tabular}{|c|c|c|c|}
\hline $\begin{array}{l}1 \text { - 'It is important to feel yourself as a part of civic } \\
\text { community' } \\
6 \text { - 'It is important to feel yourself as a personality, but not a } \\
\text { citizen of the country' }\end{array}$ & 2 & 4 & 3 \\
\hline $\begin{array}{l}1 \text { - 'A human must live and work in the country of } \\
\text { citizenship' } \\
6 \text { - 'There is no bad to leave the country in the hard and } \\
\text { difficult period' }\end{array}$ & 2 & 4 & 3 \\
\hline $\begin{array}{l}1 \text { - 'Citizen must abide the laws' } \\
6 \text { - 'In some situations it is possible to act outside the law' }\end{array}$ & 1 & 4 & 3 \\
\hline $\begin{array}{l}1 \text { - 'Each citizen must actively participate social-political } \\
\text { events, support any particular party, front or movement' } \\
6 \text { - 'Policy is a 'duty business', one can be a good citizen } \\
\text { outside the policy' }\end{array}$ & 3 & 5 & 4 \\
\hline $\begin{array}{l}1 \text { - 'First, one must take care about own well-being but not } \\
\text { about the others and society in whole' } \\
6 \text { - 'Everybody must think not only about him/herself but } \\
\text { about surroundings and own country' }\end{array}$ & 3 & 4 & 3 \\
\hline $\begin{array}{l}1 \text { - 'There is no any sense to break the situation alone, } \\
\text { something can be done only by the government' } \\
6 \text { - 'One shouldn't hope for the government, the most part of } \\
\text { the problems could be solved in cooperation by common } \\
\text { efforts' }\end{array}$ & 3 & 4 & 3 \\
\hline $\begin{array}{l}1 \text { - 'My interests must be protected from the governmental } \\
\text { influence' } \\
6 \text { - 'Sometimes, for common well-being, the state may } \\
\text { interfere the private business of own citizens' }\end{array}$ & 3 & 3 & 3 \\
\hline
\end{tabular}

Parts of representatives of the abovementioned groups are differ depending on the territory of residence $\left(\chi^{2}, \mathrm{p}<0.01\right.$, table 3$)$. Parts of the first 'pro-governmental' group are larger in the Jewish Autonomous oblast and smaller in the Kemerovo oblast and the Orenburg oblast. Representatives of the second 'individualistic' group are mostly presented in the Orenburg oblast and lesser - in the Altai krai.

Table 3. Distribution of groups depending on attitudes to the characteristics of citizenship in six Russian subjects, $\%$.

\begin{tabular}{|l|c|c|c|}
\hline $\begin{array}{c}\text { Subject of the Russian } \\
\text { Federation }\end{array}$ & $\begin{array}{c}\text { 1 (citizen is } \\
\text { inseparable from the } \\
\text { state) }\end{array}$ & $\begin{array}{c}2 \text { (citizen is absolutely } \\
\text { autonomous) }\end{array}$ & $\begin{array}{c}3 \text { (average } \\
\text { positions) }\end{array}$ \\
\hline Altai krai & 32.1 & 16.2 & 51.7 \\
\hline $\begin{array}{l}\text { Jewish Autonomous } \\
\text { oblast }\end{array}$ & 39.9 & 20.7 & 39.4 \\
\hline Transbaikal krai & 30.2 & 23.5 & 46.3 \\
\hline Kemerovo oblast & 26.6 & 21.3 & 52.1 \\
\hline Omsk oblast & 33.1 & 20.9 & 46.1 \\
\hline Orenburg oblast & 21.2 & 34.8 & 44.0 \\
\hline
\end{tabular}

Attitudes about subjects of help in case of emergency may describe the evaluations of civil society organizations (table 4). In case of violation of civil rights, the majority of Russians (78.8\%) will appeal to the close surroundings (family, friends, colleagues, community). At the second place are law-enforcement agencies $-33.9 \%$ will come to them, 
first; at the third place - human rights and other public organizations (22.4\%), but the majority of respondents will appeal for help for the second turn. In the last turn respondents will appeal to the mass media, Internet, and the governmental bodies of different level.

Table 4. Distribution of answer on the question: 'Whom do you appeal for help and protection in the first turn in case of violation of your civic or political rights? And, in the second turn if no help?

And, in the third turn if the first two attempts failed?', \%.

\begin{tabular}{|l|c|c|c|}
\hline & $\begin{array}{c}\text { In the first } \\
\text { turn }\end{array}$ & $\begin{array}{c}\text { In the second } \\
\text { turn }\end{array}$ & $\begin{array}{c}\text { In the } \\
\text { third turn }\end{array}$ \\
\hline $\begin{array}{l}\text { Close surroundings (family, friends, colleagues, } \\
\text { community) }\end{array}$ & 78.8 & 14.2 & 6.9 \\
\hline Human rights and other public organizations & 22.4 & 51.0 & 26.7 \\
\hline $\begin{array}{l}\text { Law-enforcement agencies (police, court, } \\
\text { prosecutor's office) }\end{array}$ & 33.9 & 41.4 & 24.7 \\
\hline Bodies of local or regional government & 12.1 & 39.9 & 47.9 \\
\hline Administration of the President, federal government & 9.2 & 26.0 & 64.8 \\
\hline Mass media, Internet & 14.0 & 25.2 & 60.8 \\
\hline
\end{tabular}

Functioning of civil society occurs in a result of self-organized activity of citizens. According to the obtained data, almost a half of respondents are occupied with any sociallyuseful activity (53.4\%). The most spread form of public activity is provision of any help (by money, food or stuff) -about $48.4 \%$ of respondents were occupied with such activity. The following types of the activity are also wide spread in Russia: money depositing to charity funds and in the carrying out of charity actions (20.9\%), volunteer work (20.9\%), application to authorities (17.9\%), signing petitions and collective applications $(15.7 \%)$. The less spread are public speeches for anything's or anybody's support $(5.1 \%)$ and participation in protest actions $(4.9 \%)$.

Rather small part of the Russians participates in the activity of public organizations (37.3\%). First of all, charity organizations (22.4\%), territorial self-governing (20.3\%), and professional unions (19.9\%) are the most popular. $12.2 \%$ of respondents marked participation in the activity of the youth organizations, the other types of non-governmental organizations (human rights, religious, political, and ecological ones) attract no more than $10 \%$ of citizens.

Only $16.6 \%$ of respondents interact with non-governmental organizations that probably may testify about bad knowledge of the essence of non-governmental activity the term itself. Sometimes the term 'non-governmental organizations' was considered as not equate to public organizations (15.2\% of respondents found difficulty in replying). Thus, according to the Research group ZIRCON data, in 2012 the part of citizens who never heard about non-governmental organizations constitutes 44\% [23]. By data of the Center on Political Technologies, in 2013 the level of information about non-governmental organizations was about $14.8 \%$ [24].

$1.3 \%$ of respondents are the leaders of non-governmental organizations, $4.8 \%$ collaborators, $3.7 \%$ - volunteers, $4.3 \%$ - active participators of events and projects, and $2.4 \%$ ever provided material aid to non-governmental organizations. Respondents with different social-demographic characteristics have different level of social activity $(\chi 2$, $\mathrm{p}<0.05)$. People with unfinished higher and higher level of education, having high level of material well-being and representatives of groups at the age between 18 and 29 and between 30 and 49 years are fully occupied with the activity of non-governmental organizations. The youth rather often act as volunteers, but respondents and the middle age rather often act as employers at such organizations. The young respondents prefer youth organizations and organizations of supplementary education, the respondents at the middle age rather often are members of trade unions and communities, and the persons of the elderly age often engaged in local self-government. Also note that the youth have higher 
readiness to participate social work as volunteers. Evident correlation was fixed between the level of material well-being and part of participants of the activity of charity and political organizations, and volunteers and public supporters of something also: the higher the income the higher the activity. People with low incomes often participate in protest actions, sign applications and petitions. People with high level of education rather often occupied with charity and organizations and sign petitions.

Participation in activity of non-governmental organizations differs in different regions of Russia. The most active are citizens of the Transbaikal region (25.3\% of engaged respondents), the Jewish Autonomous oblast (23.1\%), and the Altai krai (20.8\%), the less involved are citizens of the Omsk oblast (13.5\%) and the Orenburg oblast (12.1\%), citizens of the Kemerovo oblast are almost not active (5.0\%).

To evaluate conditions of development of the civil society we formulated 25 statements and suggested respondents to estimate them on 10-point scale: from 1 point (the less expressed) to 10 points (the most expressed). In total sampling mean evaluations varied from 4.03 to 6.16 points, mean evaluation of all statements was 4.76 points. Statements about ethnic and religious tolerance were estimated as highly expressed. The less expressed were the effectiveness of laws on prevention of corruption (table 5).

Among considered regions, the more favorable conditions were in the Jewish Autonomous oblast (5.36 points) and the Orenburg oblast (5.24 points), not so high evaluation were fixed in the Altai region (4.63 points), the Omsk oblast (4.62 points) and the Kemerovo oblast (4.57 points). The lowest evaluations were in the Transbaikal krai (4.17).

The highest range between regions were fixed in evaluations of such characteristics as 'Tolerance to persons of other ethnos' and 'Tolerance to people of other religion': in the Omsk oblast mean values were equal to 7.51 and 7.30 points correspondingly, and in the Transbaikal krai - 5.04 and 5.09 with 6.16 and 6.10 in total sampling. Considerable differences were fixed in evaluations about justice in the access to health care services (in the Orenburg oblast the mean value was equal to 5.71 points, and in the Transbaikal krai 3.86 with 4.69 in total sampling) and efficiency of the system of regional governing (5.09 in the Kemerovo oblast and 3.37 in the Transbaikal krai with 4.40 in total sampling).

Table 5. Evaluations about the expression of conditions for development of civil society (mean values, 10-point scale).

\begin{tabular}{|l|c|}
\hline Tolerance to people of other ethnos & 6.16 \\
\hline Tolerance to people of other religion & 6.10 \\
\hline Free, responsible mass media are objective about social problems & 5.06 \\
\hline $\begin{array}{l}\text { Executive government are effective in realization of authorities and functions in the } \\
\text { fields of cultural, education and health care services }\end{array}$ & 5.02 \\
\hline Authorities between federal center and districts are rationally divided & 5.02 \\
\hline Regular, free and honest elections & 4.99 \\
\hline Provision of equal access to education services & 4.95 \\
\hline Local self-government - empowered authority, having means to implement the power & 4.85 \\
\hline Executive government effectively realizes functions about supervision and control & 4.83 \\
\hline Supremacy of the law, protected by independent courts, transparency of court's activity & 4.75 \\
\hline $\begin{array}{l}\text { Executive government are effective in realization of authorities and functions on control } \\
\text { of law enforcement }\end{array}$ & 4.72 \\
\hline $\begin{array}{l}\text { Executive government are effective in realization of authorities and functions on } \\
\text { management about state properties }\end{array}$ & 4.71 \\
\hline
\end{tabular}




\begin{tabular}{|l|c|}
\hline Justice in the access to health care services & 4.69 \\
\hline Parties are real instrument of power formation and lobbying of public interests & 4.63 \\
\hline Executive government creates laws which protect rights and interests of electorate & 4.63 \\
\hline Native business is socially responsible & 4.60 \\
\hline $\begin{array}{l}\text { Non-commercial sector is qualitatively developed, non-commercial organizations really } \\
\text { provide social services to population and provide public expertise }\end{array}$ & 4.53 \\
\hline Dialogue of the state and society by taking significant decisions is effective and public & 4.47 \\
\hline Evaluation of activity of government is effective and considers public option & 4.45 \\
\hline Regional government is effective in the realization of conflicts & 4.42 \\
\hline Support for non-commercial initiatives is organized & 4.42 \\
\hline Effective system of regional governance is formed & 4.40 \\
\hline $\begin{array}{l}\text { Economy with protection of private property, provision of equal opportunities and } \\
\text { guarantees for disadvantaged }\end{array}$ & 4.38 \\
\hline Trade unions are uncompromising in protection of employer's interests & 4.29 \\
\hline Laws on prevention of corruption are effective & 4.03 \\
\hline
\end{tabular}

\section{Conclusions}

Results of the realized research let to conclude about predispositions for self-organizations and participation in the activity of civil society institutes in the consciousness of the Russians: we fixed the feeling of unity with compatriots and some extent of responsibility for local communities, understanding of significance of law culture, and attitudes about the necessity of public control for the government and advantages of involvement into free associations. Besides, the majority tend to opinion about the possibilities of nongovernmental organization in protection of citizen's interests. However, the attitudes about true citizen are not similar for every Russian. There positions as about the priority of the civil duty and necessity to support the state as about the personal independency from civil community.

Among one of the barriers to the civil society development is the absence of confidence about mutual understanding and cooperation between citizens of different social positions and the opinion about disagreement and fragmentation in the society. In total, condition of social-political conditions of development of civil society in regions was evaluated as rather low. The less expressed are dialogues between the state and society in taking socially significant decisions, support of civic initiatives, protection of properties and equal opportunities in the economy, prevention of corruption.

Among all observed regions, the most favorable is the situation in the Transbaikal region: there are the highest involvement into activity of non-commercial organizations and the highest evaluations about level of civil society development. In the Orenburg oblast there are also high evaluations of conditions for civil society development but the level of civic cavity is rather low. In the Altai krai and the Omsk oblast we fixed mean values among presented regions. The less level of civic activity was in the Kemerovo oblast. In the Transbaikal krai with rather high values of indexes of civic participation and social responsibility, the conditions of civil society development were extremely low estimated, the efficiency of the government system and dialogue between the state and society especially.

\section{References}


1. V. V. Ryabev, MGTU Bulletin 13, 2, pp. 439-445 (2010)

2. S. G. Maximova, N. P. Goncharova, O. E. Noyanzina, Socially oriented noncommercial organizations in Russian Federation: condition and perspectives, 306 (Alt. St. Univ. Pub. H., 2013)

3. D. Omelchenko, S. Maximova, G. Avdeeva, N. Goncharova, O. Noyanzina, O. Surtaeva, Procedia - Social and Behavioral Sciences, 190, pp. 364-371 (2015)

4. S. G. Maximova, O. Ye. Noyanzina, D. A. Omelchenko, M. B. Maximov \& G. C. Avdeeva, International journal of environmental \& science education, 11, 11, pp. 4885-4893 (2016)

5. Report on condition of the civil society in Russian Federation in 2015, 238 (2015)

6. T. A. Zamiralova, D. I. Ivanova, A. V. Krotov, Civil society in Russia: history and modernity, p. 184 (ZRNC, 2010)

7. A. Ferguson, Essay on the history of the civil society, 391 (In Russian, 2000)

8. D. Boaz, Libertarianism: A Primer (In Russian, 2004)

9. J. Locke, Two Treatises of Government, 668, 3 (1988)

10. I. Kant, Metaphysik der Sitten, 156 4, 2 (1965)

11. J. J. Rousseau, Discours sur l'origine et les fondements de l'inegalite parmi les homines, 68 I (1973)

12. E. N. Makshaeva, Theory of civil society and its formation in Russia (Candidate's thesis), p. 171 (2006)

13. G.W.F. Hegel, Grundlinien der Philosophie des Rechts, 524 (1990)

14. K. Marx, F. Engels, Die deutsche Ideologie, 3 (1960)

15. A. Gramsci, Prison Notebooks, 526 (1991)

16. T. Parsons, The System of Modern Societies, 270 (1998)

17. E. Shils, American Sociology, pp. 311-359 (1972)

18. N. Luhmann, Soziale Systeme. Grundriss einer allgemeinen Theorie, pp. 41-64 (1989)

19. I. Progozhin, Order from the Chaos. New dialogue between human and nature, 432 (1991)

20. V. N. Kortashov, YzGU Bullenin, 1, pp. 37-43 (2009)

21. E.A. Popov, S.G. Maximova, Sociodynamics, 2, pp, 269-321 (2013)

22. S. G. Maximova, O. E. Noaynzina, N. P. Goncharova, AGAU Bulletin, 4,102, p. 117121 (2013)

23. V. Moisov, L. Shubina, ZIRCON (2012)

24. Report ZPT: Civil society - a resource of development of Russia (2013) 